\title{
Adult-onset median raphe cyst of the penis
}

\author{
Jorge Navarrete 이, 1,2 Christopher B Bunker 다, ${ }^{3}$ Magdalena Vola, ${ }^{2,4}$ \\ Caroline Agorio ${ }^{2}$
}

'Department of Dermatology, Hospital Padre Hurtado,

Santiago, Chile

${ }^{2}$ Male Genital Dermatology Unit, Hospital de Clínicas Doctor Manuel Quintela, Montevideo, Uruguay

${ }^{3}$ Department of Dermatology, University College London Hospitals NHS Foundation Trust, London, UK

${ }^{4}$ Department of Dermatology, Hospital de Clínicas Doctor Manuel Quintela, Montevideo, Uruguay

Correspondence to

Professor Christopher B Bunker; cbbunker@me.com

Accepted 12 December 2020

\section{DESCRIPTION}

An otherwise healthy 23-year-old man presented to our male genital dermatology unit with an 8 -week history of sudden postcoital appearance of a preputial growth (figure 1A). This asymptomatic lesion had a fibroelastic consistency. Dermoscopic examination showed a translucent, structureless skin-coloured lesion, with no visible punctum (figure 1B). The patient recalled a barely discernible papule in this region since childhood.

Doppler ultrasound ruled out a vascular lesion and no contiguity with the urethra (figure $2 \mathrm{~A}$ ). Incisional biopsy confirmed a congenital median raphe cyst (MRC) (figure 2B). Due to the patient's aesthetic concerns, the whole cyst and capsule were later excised without complications. There has been no recurrence after 24 months of follow-up.

Theories regarding the origin of MRC include abnormal closure of the urethra during embryogenesis or the presence of ectopic periurethral glands of Littre proliferating into epithelial cavities. ${ }^{1}$

MRC is usually diagnosed during infancy. However, a subset of cases may be small and quiescent, only becoming evident during adulthood due to trauma (including coitus) and/or infection, after entering a secretory phase. ${ }^{2}$

Although MRCs are usually located along the midline (anywhere between the meatus and
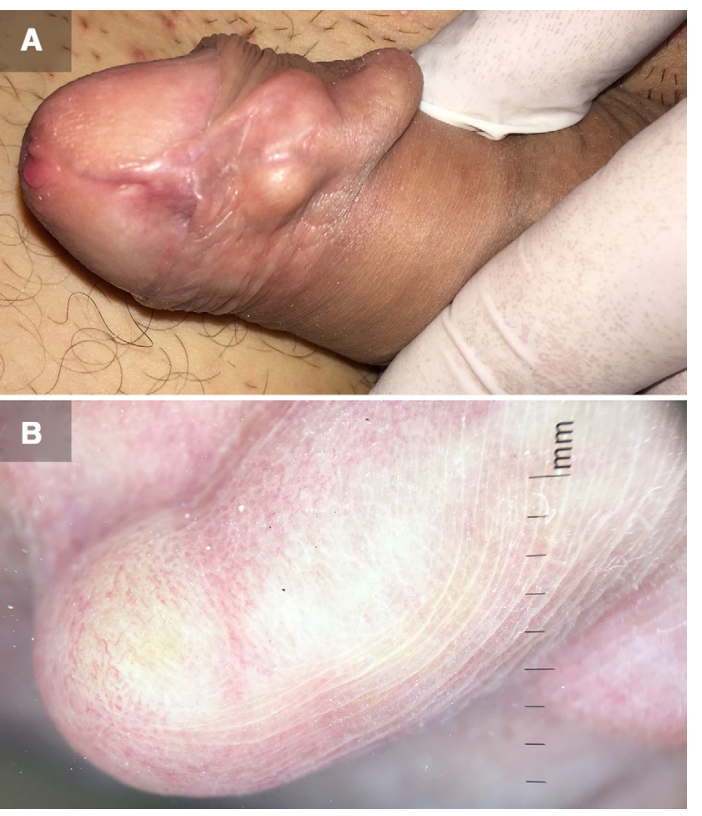

Figure 1 (A) Clinical image shows a paramedial elongated growth. (B) Dermoscopic image reveals a translucent skin-coloured lesion.
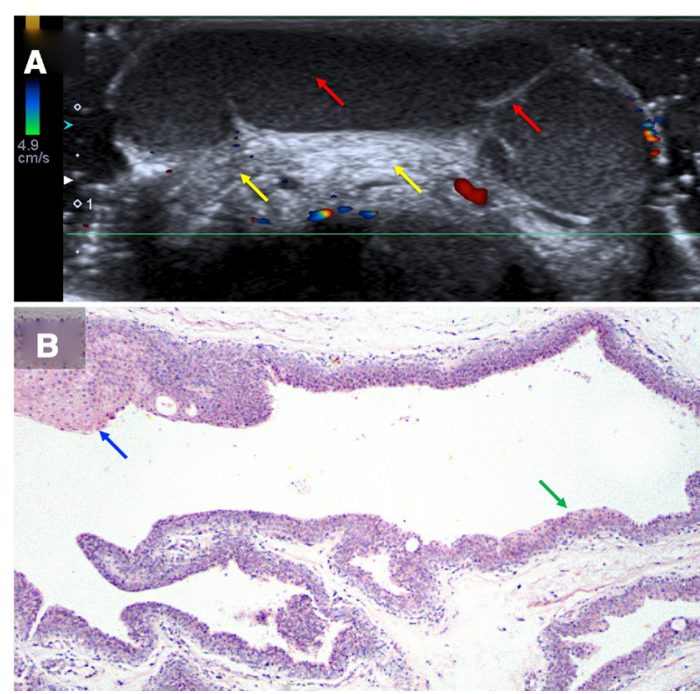

Figure 2 (A) Doppler ultrasound shows a thin-walled, anechogenic, septated cavity (red arrows), unconnected to the urethra, surrounded by normal-looking tissue (yellow arrows). (B) Histopathology with H\&E stain (original magnification $4 \times$ ) reveals an empty cystic cavity, with a mixed-lining composed of stratified squamous non-keratinising epithelium (blue arrow) and urothelium (green arrow).

perineum), they can sometimes be paramedial, making clinical diagnosis more challenging. ${ }^{3}$

We describe for the first time the dermoscopic image of MRC in adulthood. Dermoscopy can be helpful in the evaluation of inflammatory, infectious and tumorous genital dermatoses, enhancing clinical diagnosis. ${ }^{4-7}$ In our case, the absence of a punctum is a relevant finding, since important differentials are possessed of a punctum, such as epidermal cysts and penile pilonidal sinus/cysts. ${ }^{89}$ Translucency is highly suggestive of a cystic entity, however, definitive diagnosis can only be achieved histologically. We emphasise the importance of Doppler ultrasonography prior to biopsy because a diagnosis of Mondor's disease or sclerosing lymphangitis can be made on a clinical-radiological basis in most cases. ${ }^{10}$ An ultrasound also excludes contiguity with the urethra, such as with an urethral diverticulum; this could be clinically and dermoscopically indistinguishable from an MRC; a biopsy or excisional surgery could threaten the urethra and create a fistula. Doppler ultrasound imaging and histopathological images must always be interpreted in conjunction with clinical (including dermoscopic) findings. Hence, when in doubt, such cases should be evaluated by an expert urologist. ${ }^{11}$ 


\section{Learning points}

- Median raphe cyst must be considered in the differential of preputial growths in children and adults, even if paramedial.

- Dermoscopy can assist in clinical evaluation, narrowing the differential, showing a translucent image and the absence of a punctum.

- Doppler ultrasound should be done before considering a biopsy or planning an excision.

Contributors JAN has contributed to the following: Substantial contributions to the conception and design of the work; as well as the acquisition, analysis and interpretation of data for the work; Drafting the work; Final approval of the version to be published; Agreement to be accountable for all aspects of the work in ensuring that questions related to the accuracy or integrity of any part of the work are appropriately investigated and resolved. CBB, MV and CA have contributed to the following: Substantial contributions to the conception or design of the work; Revising it critically for important intellectual content; Final approval of the version to be published; Agreement to be accountable for all aspects of the work in ensuring that questions related to the accuracy or integrity of any part of the work are appropriately investigated and resolved.

Funding The authors have not declared a specific grant for this research from any funding agency in the public, commercial or not-for-profit sectors.

Competing interests None declared.

Patient consent for publication Obtained.

Provenance and peer review Not commissioned; externally peer reviewed.

\section{ORCID iDs}

Jorge Navarrete http://orcid.org/0000-0002-8563-0364

Christopher B Bunker http://orcid.org/0000-0002-6693-7483

\section{REFERENCES}

1 Lezcano C, Chaux A, Velazquez EF, et al. Clinicopathological features and histogenesis of penile cysts. Semin Diagn Pathol 2015;32:245-8.

2 Sharkey MJ, Grabski WJ, McCollough ML, et al. Postcoital appearance of a median raphe cyst. J Am Acad Dermatol 1992;26:273-4.

3 Willis HL, Snow BW, Cartwright PC, et al. Parameatal urethral cysts in prepubertal males. J Urol 2011;185:1042-5.

4 Borghi A, Virgili A, Corazza M. Dermoscopy of inflammatory genital diseases: practical insights. Dermatol Clin 2018;36:451-61.

5 Chan S-L, Watchorn RE, Panagou E, et al. Dermatoscopic findings of penile intraepithelial neoplasia: Bowenoid papulosis, Bowen disease and erythroplasia of Queyrat. Australas J Dermatol 2019;60:201-7.

6 Micali G, Lacarrubba F. Augmented diagnostic capability using videodermatoscopy on selected infectious and non-infectious penile growths: using Vd on selected infectious and non-infectious penile growths. Int I Dermatol 2011;50:1501-5.

7 LaCarrubba F, Tedeschi A, Francesconi L, et al. Canal versus cysts of the penile median raphe: advancing diagnostic methods using videodermatoscopy. Pediatr Dermatol 2010;27:667-9.

8 Suh KS, Kang DY, Park JB, et al. Usefulness of dermoscopy in the differential diagnosis of ruptured and unruptured epidermal cysts. Ann Dermatol 2017;29:33.

9 Navarrete J, Kutscher P, Fiorella D, et al. Image gallery: pilonidal sinus of the penis. $\mathrm{Br} J$ Dermatol 2017;177:e354.

10 Dell'Atti L. Role of ultrasonography with color-Doppler in diagnosis of penile Mondor's disease. J Ultrasound 2014;17:239-41.

11 Thakur N, Sabale VP, Mane D, et al. Male urethral diverticulum uncommon entity: our experience. Urol Ann 2016;8:478.

Copyright 2020 BMJ Publishing Group. All rights reserved. For permission to reuse any of this content visit

https://www.bmj.com/company/products-services/rights-and-licensing/permissions/

BMJ Case Report Fellows may re-use this article for personal use and teaching without any further permission.

Become a Fellow of BMJ Case Reports today and you can:

- Submit as many cases as you like

- Enjoy fast sympathetic peer review and rapid publication of accepted articles

- Access all the published articles

- Re-use any of the published material for personal use and teaching without further permission

Customer Service

If you have any further queries about your subscription, please contact our customer services team on +44 (0) 2071111105 or via email at support@bmj.com.

Visit casereports.bmj.com for more articles like this and to become a Fellow 